\title{
THE ACTION OF THE PHOSPHATASES OF HUMAN BRAIN ON LIPID PHOSPHATE ESTERS
}

\author{
BY \\ K. P. STRICKLAND*, R. H. S. THOMPSON, and G. R. WEBSTER \\ From the Department of Chemical Pathology, Guy's Hospital Medical School, London
}

Much work, using both histochemical and standard biochemical techniques, has been carried out on the phosphatases of peripheral nerve. It is known that this tissue contains both alkaline (Landow, Kabat, and Newman, 1942) and acid phosphatases (Wolf, Kabat, and Newman, 1943), and the changes in the levels of these enzymes in nerves undergoing Wallerian degeneration following transection have been studied by several groups of investigators (see Hollinger, Rossiter, and Upmalis, 1952).

Phosphatase activity in brain was first demonstrated by Kay (1928), and in 1934 Edlbacher, Goldschmidt, and Schläppi, using ox brain, showed that both acid and alkaline phosphatases are present in this tissue. Since that time the phosphatases have been studied in the brains of the rat, dog, sheep, rabbit, and man by a number of workers (Giri and Datta, 1936 ; Fleischhacker, 1938 ; Gordon, 1950 ; Reis, 1951 ; Naidoo and Pratt, 1951 ; Soulairac and Desclaux, 1951 ; McNabb, 1951 ; Pratt, 1953 ; Lowry, Roberts, Wu, Hixon, and Crawford, 1954). Few reports, however, are available on the distribution of the phosphatases in the grey and white matter of the brain. In dog brain McNabb (1951) has shown that both acid and alkaline phosphatases are more plentiful in grey matter than in white, but little work on their localization in human brain has so far been reported.

Furthermore, most of the studies on phosphatases have been carried out using either $\alpha$ - or $\beta$-glycerophosphate as substrate, or else with such unphysiological esters as phenyl phosphate, $\alpha$-naphthyl phosphate, or phenolphthalein phosphate. Since, however, break-up of the fatty myelin sheath is one of the outstanding changes in the lesions of multiple sclerosis and the other demyelinating diseases, it would seem desirable to obtain more knowledge concerning the enzymic reactions associated with myelin synthesis and degradation. It was decided

* Post-doctorate Overseas Fellow, National Research Council of Canada. therefore to study the action of the phosphatases ing human brain on the "lipid phosphate esters", i.e., on the various monophosphate esters that occuion in the sphingomyelins, cephalins, and lecithins. In addition to $\alpha$ - and $\beta$-glycerophosphate we have therefore used phosphoryl choline, phosphorytw ethanolamine, phosphoryl serine, and inositos. monophosphate as substrates for the phosphomonoesterases, and have measured their rates of hydrolysis by brain preparations over the $p \mathrm{H}$ rangec 4.5 to $10 \cdot 0$.

Plimmer and Burch (1937) had earlier reportêd that phosphoryl choline and phosphoryl ethanof - -은 amine are hydrolysed by the phosphatases of bore, kidney, and intestine, but the $p \mathrm{H}$ at which the hyd lyses were carried out was not given. In a later paper (Plimmer, 1941) it was reported that phe phoryl serine is hydrolysed by kidney and intestime phosphatase at $p \mathrm{H} 6 \cdot 5$. Roche and Bouchilloieㅇ (1947) have also stated that phosphoryl choline andos phosphoryl ethanolamine are split by both acid and alkaline phosphatases; they used dog liver and intestine and beef kidney as enzyme sources, and showed that at $p \mathrm{H} 9$ these esters are split at aboun the same rate as glycerophosphate. At pH 5.6, ando using dog liver, human prostate, and beef kidney as enzyme sources, they also obtained splitting of these substrates, but at a lower rate than glycerophosphate. We have been unable to find any account of the action of phosphatases of the nervous system on either phosphoryl ethanolamine or phosphoryl serine. Baccari (1948), however, has studied the hydrolysis of phosphoryl choline by preparations of both horse intestine and brain ; he् found that it was rapidly hydrolysed by the alkaline phosphatase ( $p \mathrm{H} 10$ to 11) but that it was unaffected by the acid phosphatase.

In addition to reporting on the action of the phosphatases of the human brain on these lipie. phosphate esters, a few observations are alson described on the distribution of acid and alkaline phosphatases in certain areas of the central nervous system in man. 
Since it is not possible on present evidence directly to relate the chronic nerve degeneration (Barnes and Denz, 1953 ; Cavanagh, 1954) produced by tri-ortho-cresyl phosphate, diisopropylfluorophosphonate (D.F.P.), and certain other inhibitors of the cholinesterases to an inactivation of these enzymes in the nervous system (Davison, 1953 ; Thompson, 1954), it was felt that the action of these compounds should also be studied on other esterases. Although Webb (1948) had shown that the acid and alkaline phosphatases of rabbit kidney are inhibited only by high concentrations of D.F.P. $\left(10^{-3} \mathrm{M}\right.$ or higher), it was thought desirable to investigate the action of tri-ortho-cresyl phosphate and D.F.P. on the phosphatases of brain. The effect of eserine has also been examined, although there is no evidence that this compound produces chronic nerve lesions.

\section{Experimental}

Enzyme Preparations.- Human brain and spinal cord, obtained as soon as possible after necropsy, were used for the enzyme preparations.

Dialysed Homogenates.-Homogenates (1 g. brain/ $3 \mathrm{ml} . \mathrm{H}_{2} \mathrm{O}$ ) of cortical grey matter, basal ganglia, subcortical white matter, corpus callosum, and spinal cord (lumbar region) were prepared as described by Webster (1954). These homogenates were dialysed in sausage skin sacs against distilled water at 0 to $4^{\circ} \mathrm{C}$. for 20 to 24 hours. The dialysed homogenates were then either used directly for phosphatase assays or were acetone dried.

Acetone-dried Preparations.-Dialysed homogenates of cortical grey and subcortical white matter were treated with 4 volumes of ice-cold acetone. The precipitate was centrifuged down and resuspended in ice-cold acetone. The precipitate was filtered off under suction and dried in air with the aid of a small volume of ether. This dried powder was dispersed in water (a weight equivalent to $250 \mathrm{mg}$. fresh wt. $/ \mathrm{ml}$.) 15 minutes before it was to be used as a source of phosphatase.

Buffers.-All buffers were adjusted to the desired $p \mathrm{H}$ with the Cambridge $p \mathrm{H}$ meter.

$0.2 \mathrm{M}$ Acetate buffer was used for the $p \mathrm{H}$ range 4.5 to 5.9.

$0 \cdot 2 \mathrm{M}$ Glycylglycine. This buffer was used for the $p \mathrm{H}$ range 6.5 to $8 \cdot 0$.

$0 \cdot 2 \mathrm{M}$ Carbonate-bicarbonate. This buffer was used for the $p \mathrm{H}$ range 8.0 to 10.0 .

Substrates.-Stock solutions $(0 \cdot 15 \mathrm{M})$ of each substrate were prepared. For phosphatase assays $0.2 \mathrm{ml}$. of this stock solution was added; for a final volume of $3 \mathrm{ml}$. this gives a concentration of $10^{-2} \mathrm{M}$.

The following substrates were used :-

Sodium phenyl phosphate (British Drug Houses Ltd.)

Sodium $\alpha$-naphthyl phesphate (Hopkin \& Williams Ltd.) Ltd.)

Sodium phenolphthalein diphosphate (L. Light \& Co.

Sodium $\alpha$-glycerophosphate (L. Light \& Co. Ltd.)

Sodium $\beta$-glycerophosphate (British Drug Houses Ltd.)
Phosphoryl Choline.-This substrate was prepared as the calcium salt by the method of Riley (1944). Calcium was removed from a solution of this salt by the addition of sodium oxalate.

Phosphoryl Ethanolamine.-The barium salt of this compound was prepared according to the method of Outhouse (1937). Barium was removed from a solution of this salt by adding $\mathrm{Na}_{2} \mathrm{SO}_{4}$ until no further precipitation of $\mathrm{BaSO}_{4}$ occurred.

Phosphoryl Serine.-The barium salt of phosphoryl setine was prepared essentially according to the method of Plimmer (1941). It was found necessary to use $100 \%$ $\mathrm{H}_{3} \mathrm{PO}_{4}$ in the preparation. This was obtained by removing the water from syrupy $\mathrm{H}_{3} \mathrm{PO}_{4}$ (s.g. 1.75) in vacuo at $145^{\circ} \mathrm{C}$., aided by a soxhlet thimble, filled with $\mathrm{P}_{2} \mathrm{O}_{5}$ and asbestos fibre, suspended over the acid. On cooling long, plate-like crystals formed ; this crystalline $\mathrm{H}_{3} \mathrm{PO}$, was dried over $\mathrm{P}_{2} \mathrm{O}_{5}$. As for phosphoryl ethanolamine, barium was removed in the form of the insoluble sulphate.

Inositol Monophosphate.-A crude preparation of free inositol monophosphate was obtained using the method outlined in Biochemical Preparations (McCormick and Carter, 1952).

Inhibitors.-A fresh solution of each of the cholinesterase inhibitors was prepared of sufficient strength that $0.2 \mathrm{ml}$. of this solution in a final volume of $3 \mathrm{ml}$. gave the desired concentration. The following inhibitors were used : eserine sulphate (British Drug Houses Ltd.); D.F.P., kindly provided by the Ministry of Supply, Experimental Station, Porton, Wilts ; and tri-orthocresyl phosphate (T.O.C.P.) (Geigy Pharmaceutical Laboratories, Ltd.).

Incubation and Sampling.-For each experiment stoppered tubes were set up containing $1.5 \mathrm{ml}$. of buffer, $0.5 \mathrm{ml}$. of enzyme preparation, $0.1 \mathrm{ml} .0 .03 \mathrm{M}$ $\mathrm{MgCl}_{2}$, and $0.7 \mathrm{ml}$. water $(0.9 \mathrm{ml}$. water for tubes containing no substrate). The tubes were warmed to $38^{\circ} \mathrm{C}$. and then $0.2 \mathrm{ml}$. of substrate was added to each tube. One-millilitre samples were taken immediately following addition of the substrate and after 60 minutes incubation with shaking at $38^{\circ} \mathrm{C}$. Each sample was added to $1.5 \mathrm{ml} .8 \cdot 3 \%$ trichloroacetic acid in order to stop the enzyme reaction and to precipitate the protein.

The precipitate was centrifuged and a portion of the supernatant was used for the inorganic phosphate analysis.

Estimation of Inorganic Phosphate.-Inorganic phosphate (ortho) was estimated according to the method of Ernster, Zetterström, and Lindberg (1950). One millilitre of the above supernatant was added to a stoppered tube containing $5 \mathrm{ml} .1: 1$ isobutanol : benzene, $3.5 \mathrm{ml}$. $5 \%$ trichloroacetic acid, and $0.5 \mathrm{ml} .60 \%$ perchloric acid. Then $0.5 \mathrm{ml}$. of $10 \%$ ammonium molybdate was added and the tube stoppered and shaken vigorously for 30 seconds ; $2 \mathrm{ml}$. of isobutanol : benzene layer containing the phosphomolybdic acid complex were then diluted to $6 \mathrm{ml}$. with acid alcohol $\left(32 \mathrm{ml}\right.$. concentrated $\mathrm{H}_{2} \mathrm{SO}_{4} / 1$. absolute ethanol). The blue colour was developed by 


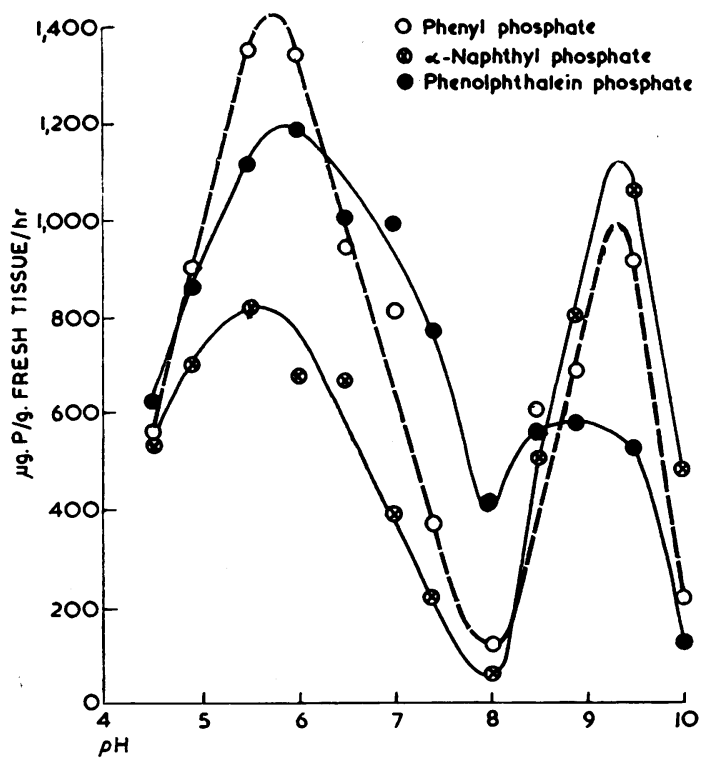

FIG. 1

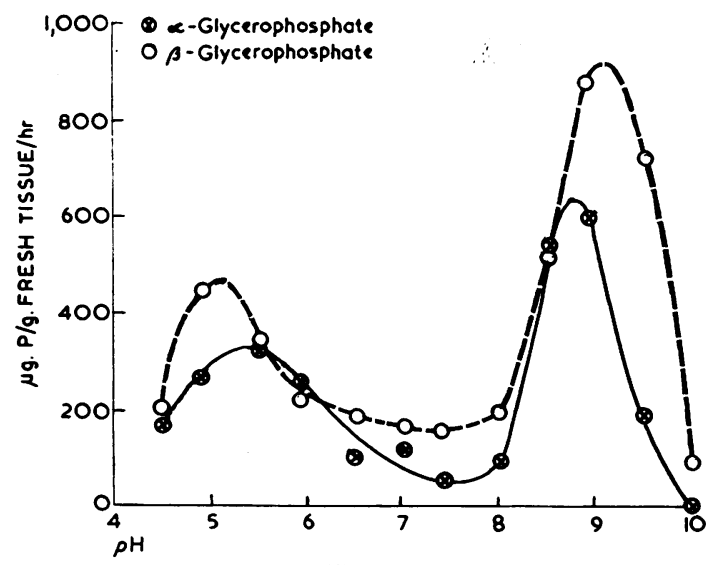

FIG. 2

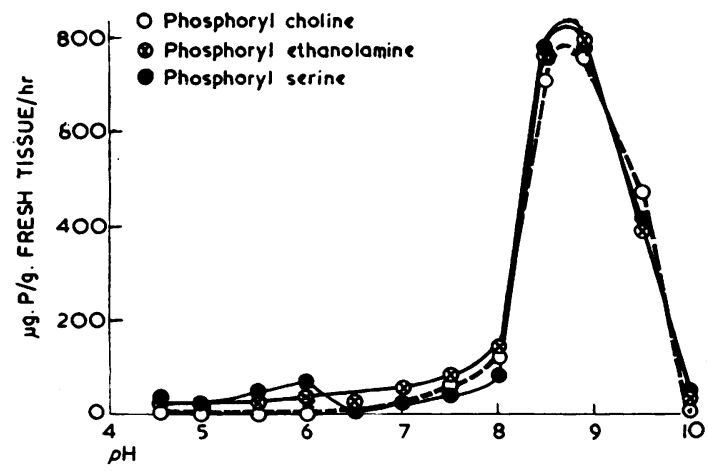

Fig. 3 adding $0.5 \mathrm{ml}$. of dilute $\mathrm{SnCl}_{2}$ (stock solution of $10 \mathrm{~g} . \bar{Z}$ $\mathrm{SnCl}_{2} 2 \mathrm{H}_{2} \mathrm{O} / 25 \mathrm{ml}$. concentrated $\mathrm{HCl}$ diluted $200 \stackrel{\text { Ф }}{\complement}$ times with $\mathrm{N} \mathrm{H}_{2} \mathrm{SO}_{4}$ ). This colour was read after 30 을 minutes on a spectrophotometer at $730 \mathrm{~m} \mu$.

Phosphatase Activity.-Phosphatase activities have been expressed in terms of $\mu \mathrm{g}$. inorganic $P$ released $/ \mathrm{g}$. (N) fresh tissue/hour. In all cases, small corrections have $\stackrel{O}{?}$ been made for inorganic phosphate released from the tissue and for non-enzymic hydrolysis of the substrate.

\section{Results}

The rates of hydrolysis of these various substrates? by acetone-dried preparations of human cerebral $\overline{\bar{c}}$ cortical grey matter over the $p \mathrm{H}$ range 4.5 to $10 \cdot 0 \frac{\bar{p}}{7}$ are shown in Figs. 1 to 3 . It will be seen (Fig. 1) that the three aromatic phosphate esters are each hydrolysed by both the acid and alkaline phos- $\overrightarrow{0}$ phatases. There does not appear to be any great $\stackrel{\circ}{-}$ difference in the $p H$ optima for these three sub- $\vec{\omega}$ strates; values ranging from 5.5 to 5.8 for the acid phosphatase and from 9.0 to 9.4 for the alkaline phosphatase being found.

The results shown in Fig. 2 indicate that under $\overrightarrow{0}$ our conditions $\alpha$ - and $\beta$-glycerophosphate atehydrolysed by the alkaline phosphatase of hum $\mathbb{M} \vec{N}$ brain at approximately the same rate as that $\mathrm{S}$ to which the aromatic esters are split. The glycere-phosphates are also split by the acid phosphatase, 7 but at a considerably lower rate than the aromatio음 esters. The $p \mathrm{H}$ optima for the glycerophosphates are in the neighbourhood of 5.1 to 5.5 and $8 \cdot 7$ to $9 \cdot 1$, for the acid and alkaline phosphatasesce respectively.

The phosphate esters of choline, ethanolamine, and serine are also each hydrolysed rapidly by the alkaline phosphatase of brain, the rates being of the same order as those for the aromatic and glycerolo esters. In contrast to these other esters, however, $\mathbb{D}$ the choline, ethanolamine, and serine esters do not appear to be hydrolysed to any significant extentoํㅡㄹ by the acid phosphatase.

The relative levels of acid and alkaline phos-胥 phatase activity in different areas of grey and white matter from the brain, and also in the spinal cord, are shown in Table $\mathrm{I}$.

There does not seem to be any noticeable dif-욱 ference in the acid or alkaline phosphatase activity

Fig. 1.-Hydrolysis of phenyl phosphate, $\alpha$-naphthyl phosphate, and phenolphthalein phosphate by acetone-dried preparations of human cerebral cortical grey matter.

FIG. 2.-Hydrolysis of sodium $\alpha$-and $\beta$-glycerophosphate by acetone $\frac{7}{2}$ dried preparations of human cerebral cortical grey matter.

Fig. 3.-Hydrolysis of phosphoryl choline, phosphoryl ethanolamine, and phosphoryl serine by acetone-dried preparations of human cerebral cortical grey matter. 
of different areas of grey (cortical grey matter and basal ganglia) or white matter (subcortical white and corpus callosum). However, as can be observed from the ratios of $2 \cdot 1$ and 4.6 for the means of the acid : alkaline phosphatase activity of grey and white matter respectively, there is much more acid phosphatase than alkaline phosphatase in each tissue. The results for spinal cord are very similar to those for white matter, there being a much more active acid phosphatase than alkaline phosphatase. At $p \mathrm{H} \mathrm{8.9,} \mathrm{mean} \mathrm{activities} \mathrm{of} 726$ for grey matter and 261 for white matter were obtained using phosphoryl ethanolamine. These values are very similar to those obtained for phenyl phosphate (Table I).

\section{TABLE I}

ACTIVITY OF ACID ( $p \mathrm{H}$ 5.5) AND ALKALINE ( $p \mathrm{H} \quad 8.9)$ PHOSPHATASES IN DIFFERENT AREAS OF HUMAN BRAIN AND SPINAL CORD*

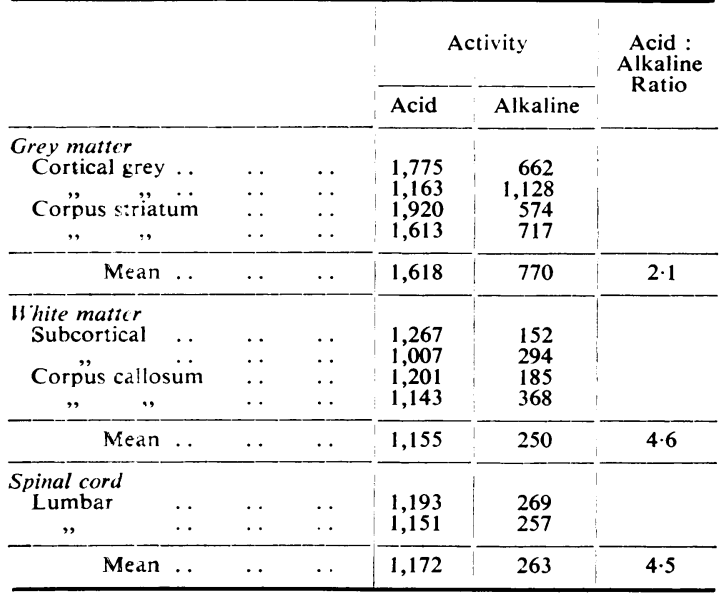

* Dialysed homogenates of each area ; phenyl phosphate as substrate. Activity expressed as $\mu \mathrm{g}$. $\mathrm{P} / \mathrm{g}$. fresh tissue $/ \mathrm{hr}$.

It will further be seen that there is very much less alkaline phosphatase in the spinal cord or the white matter of the brain than in grey matter. The acid phosphatase activity of white matter, on the other hand, is only slightly less than that of the grey. These relative proportions are summarized in Table II.

In view of the presence of phosphate esters of inositol in the diphosphoinositide component of the cephalins (Folch, 1949), the action of the brain phosphatases has been studied, in a preliminary experiment, on a crude preparation of inositol monophosphate. It was found that, using an acetone-dried powder of cortical grey matter, this substrate at $p \mathrm{H} 8.9$ was hydrolysed at a rate of $315 \mu \mathrm{g} . P$. $g$. fresh tissue/hour, but showed no significant hydrolysis at $p \mathrm{H} 5 \cdot 5$. This preliminary
TABLE II

RATIOS OF ACTIVITY OF PHOSPHATASES IN GREY AND WHITE MATTER OF HUMAN BRAIN (DIALYSED HOMOGENATES)

\begin{tabular}{c|c|c}
\hline$p \mathrm{H}$ & Substrate & $\begin{array}{c}\text { Activity of Grey Matter : } \\
\text { White Matter }\end{array}$ \\
\hline 5.5 & Phenyl phosphate & $1 \cdot 4$ \\
8.9 & Phenyl phosphate & $3 \cdot 1$ \\
8.9 & Phosphoryl ethanolamine & $2 \cdot 8$ \\
\hline
\end{tabular}

result, therefore, indicates that the pattern of hydrolysis of this substrate by brain phosphatases is similar to that shown by the other lipid phosphate esters.

The effects of the two " demyelinating" anticholinesterases and of eserine on the acid and alkaline phosphatases of human brain, using both phenyl phosphate and phosphoryl ethanolamine as substrates, are shown in Table III. It will be seen that none of these inhibitors exerted any significant effect on either type of phosphatase.

TABLE III

EFFECT OF CHOLINESTERASE INHIBITORS ON ACID AND ALKALINE PHOSPHATASE OF ACETONE-DRIED HUMAN CEREBRAL CORTICAL GREY MATTER *

\begin{tabular}{|c|c|c|c|c|c|}
\hline \multirow[b]{2}{*}{ Substrate } & \multirow[b]{2}{*}{$p \mathbf{H}$} & \multicolumn{4}{|c|}{ Phosphatase Activity in Presence of } \\
\hline & & $\begin{array}{l}\text { No In- } \\
\text { hibitor }\end{array}$ & $\begin{array}{l}\text { Eserine } \\
\left(10^{-4} \mathrm{M}\right)\end{array}$ & $\underset{\left(10^{-3} \mathbf{M}\right)}{\text { D.F.P. }}$ & $\begin{array}{c}\text { T.O.C.P. } \\
(1 \cdot 8 \times \\
\left.10^{-4} \mathrm{M}\right)\end{array}$ \\
\hline $\begin{array}{l}\text { Phenyl phosphate .. } \\
\text { Phosphoryl }\end{array}$ & $8 \cdot 9$ & 1,350 & 1,402 & 1,252 & 1,382 \\
\hline $\begin{array}{l}\text { ethanolamine } \\
\text { Phenyl phosphate } . .\end{array}$ & $\begin{array}{l}8 \cdot 9 \\
5 \cdot 5\end{array}$ & $\begin{array}{r}647 \\
1,147\end{array}$ & $\begin{array}{r}676 \\
1,315\end{array}$ & $\begin{array}{r}661 \\
1,235\end{array}$ & $\begin{array}{r}632 \\
1,189\end{array}$ \\
\hline
\end{tabular}

* Expressed as $\mu \mathrm{g} . \mathrm{P} / \mathrm{g}$. fresh tissue $/ \mathrm{hr}$.

\section{Discussion}

The experiments described above confirm the earlier findings of Gordon (1950) and Reis (1951) that both acid and alkaline phosphatases are present in human brain. It is clear, however, that the observed levels of each of these enzyme activities depend very markedly on the substrate used for their measurement. This is particularly so in the case of the acid phosphatase; thus, while the glycerophosphates are split more slowly than the aromatic esters, the lipid phosphate esters are hardly attacked at all. These latter esters would, therefore, seem to be selective substrates for the alkaline phosphatase of nervous tissue. As pointed out earlier, Baccari (1948) described a similar inactivity of the acid phosphatase of horse brain towards phosphoryl choline, and we have shown that, with human brain, this applies also to the ethanolamine and serine esters, and probably also to inositol monophosphate.

It will be seen that our study of the distribution of the phosphatases in different areas of the human 
brain has been limited to a very few regions. Nevertheless, we have not found any obvious difference between the two areas of grey or of white matter which we have investigated. From this preliminary survey it is apparent that our finding of a higher acid : alkaline phosphatase ratio in white matter than in grey supports the conclusion reached by Hollinger and others (1952) for cat sciatic nerve that the alkaline phosphatase is mainly neuronal in situation whereas the acid phosphatase is a sheath component, and suggests that in the central nervous system the latter enzyme is possibly associated with glial structures.

The experiments with the anti-cholinesterases indicate that levels of D.F.P. and T.O.C.P. higher than those that are likely to be found in the nervous system of animals poisoned by "demyelinating" doses of these compounds produce no inhibition of either type of phosphatase. This would seem to rule out any inactivation of brain phosphatases as a cause of the nerve degeneration produced by these anti-cholinesterases.

\section{Summary}

The effect of brain phosphatase preparations on a number of "lipid phosphate esters" has been studied.

It has been found that at $p \mathrm{H} 8.9$ the alkaline phosphatase of human brain hydrolyses phenyl phosphate, $\alpha$-naphthyl phosphate, phenolphthalein phosphate, $\alpha$ - and $\beta$-glycerophosphate, and the phosphate esters of choline, ethanolamine, and serine at approximately the same rate.

The acid phosphatase of human brain, on the other hand, while strongly active against the aromatic phosphate esters, hydrolyses $\alpha$ - and $\beta$-glycerophosphate relatively slowly and has virtually no effect on the lipid phosphate esters.

A crude preparation of inositol monophosphate has also been used as a substrate; like the other lipid phosphate esters this compound appears to be hydrolysed only by the alkaline phosphatase.

The acid : alkaline phosphatase ratio is considerably higher in white matter than in grey.

High concentrations of two "demyelinating " 0 anti-cholinesterases (diisopropylfluorophosphonate and tri-ortho-cresyl phosphate) have been shown to cause no inhibition of either acid or alkaline phosphatase of human brain.

We wish to thank the Medical Research Council for a grant towards the expenses of this work. Our thanks are also due to Mr. D. B. Mays for technical assistance.

\section{REFERENCES}

Baccari, V. (1948). Arch. Sci. biol. (Napoli), 32, 391.

Barnes, J. M., and Denz, F. A. (1953). J. Path. Bact., 65, 597. Cavanagh, J. B. (1954). Journal of Neurology, Neurosurgery and Psychiatry, 17, 163

Davison, A. N. (1953). Brit. J. Pharmacol., 8, 212.

Edlbacher, S., Goldschmidt, E., and Schläppi, V. (1934). Hoppe-Seyl. $\vec{\omega}$ Z. physiol. Chem., $227,118$.

Ernster, L., Zetterström, R., and Lindberg, O. (1950). Acta chem. scand., 4, 942.

Fleischhacker, H. H. (1938). J. ment. Sci., 84, 947.

Folch, J. (1949). J. biol. Chem., 177, 505 .

Giri, K. V., and Datta, N. C. (1936). Biochem. J., 30, 1089.

Gordon, J. J. (1950). Ibid., 46, 96. Gordon, J. J. (1950). Ibid., 46, 96.

Kay, H. D. (1928). Ibid., 22, $855 . \quad$ W. (1942)

Landow, H., Kabat, E. A., and Newman, W. (1942). Arch. Neurब. 웅 Psychiat. (Chicago), 48, 518.

Lowry, O. H., Roberts, N. R., Wu, M., Hixon, W. S., ađ̃ -

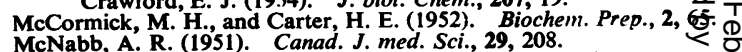

Naidoo, D., and Pratt, O. E. (1951). Journal of Neurology, Neuro-

surgery and Psychiatry, 14, 287.
Outhouse, E. L. (1937). Biochem. J., 31, 1459.

Plimmer, R. H. A. (1941). Ibid., 35, 461.

, and Burch, W. J. N. (1937). Ibid., 31, 398.

Pratt, O. E. (1953). Ibid., 55, 140.

Reis, J. L. (1951). Ibid., 48, 548.

Riley, R. F. (1944). J. Amer. chem. Soc., 66, 512

Roy, R. (1947). C $R$ Soc Biol (Paris), 141 , 1068.

Soulairac, A., and Desclaux, P. (1951). Rev. neurol., (Paris), 85, 81.

Thompson, R. H. S. (1954). Chem. and Industry, p. 749.

Webb, E. C. (1948). Biochem. J., 42, 96.

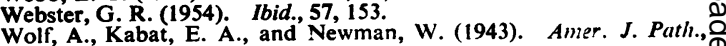
$19,423$. 